\title{
PEMBENTUKAN KELUARGA SAKINAH MAWADDAH WARAHMAH MENURUT UNDANG - UNDANG NOMOR 1 TAHUN 1974 DAN KOMPILASI HUKUM ISLAM
}

\author{
Hamsah Hudafi
}

Universitas Islam Negeri Sunan Kalijaga, bamsabhudafi0303@gmail.com

\author{
Diterima: 29 Oktober $2020 \quad$ Direvisi: 17 November $2020 \quad$ Diterbitkan: 31 Desember 2020

\section{@๑ఠ} \\ (C)2020 by the authors. Submitted for possible open access publication under the terms and conditions \\ of the Creative Commons Attribution (CC-BY-SA) license (https://creativecommons.org/licenses/by-sa/4.0/) \\ do) DOI : $\underline{10.30983 / \text { alhurriyah.v5i2.3647 }}$
}

\begin{abstract}
The formation of a sakinah mawaddah and rahmah family is a family that is desired by every married person. The purpose of a marriage and the application of the rights and obligations of husband and wife, because in this day and age we see many marriages that do not last long. This encourages the author to write an article that will discuss how to build a sakinah-mawaddah-warahmah family in accordance with the Marriage Law and Islamic Law Compilation (KHI). The writing method used a literature studies that take from existing books and writings. In this paper, there are efforts to establish a household, namely those contained in articles 30-34 of the Marrige Law and article $77 \mathrm{KHI}$ and also solutions to the formation of the samawa household. The solution is to maintain communication relationships, biological needs, appearances and regulate the family economy.
\end{abstract}

Keywords: Marriage, Rights and Obligations, Samawa's Family

\begin{abstract}
Abstrak
Pembentukan keluarga yang sakinah mawaddah dan rabmah merupakan sebuah keluarga yang diinginkan oleb setiap orang yang sudah menikah. Tujuan dari sebuah perkawinan dan penerapan hak dan kewajiban suami istri, karena di zaman sekarang banyak kita libat pernikahan-pernikahan yang tidak berlangsung lama. Hal tersebut mendorong penulis untuk menulis sebuah tulisan yang akan membahas tentang bagaimana membangun keluarga yang sakinah-mawaddah-warahmah sesuai dengan Undang-undang perkawinan dan KHI. Metode penulisan menggunakan studi literatur yang mengambil dari buku dan tulisan yang sudah ada. Dalam tulisan ini terdapat upaya pembentukan rumabtangga yaitu yang terdapat pada pasal 30-34 UUP dan pasal 77 KHI dan juga solusi pembentukan rumah tangga yang samawa. Adapun solusinya yaitu menjaga bubungan komunikasi, kebutuban biologis, menjaga penampilan dan mengatur ekonomi keluarga.
\end{abstract}

Kata kunci: Perkawinan, Hak dan Kewajiban, Keluarga Samawa 


\section{PENDAHULUAN}

Keluarga merupakan sebuah unit terkecil di dalam masyarakat, terbentuknya keluarga akibat adanya pernikahan antara seorang laki-laki dan perempuan yang saling mencintai dan disatukan dengan akad yang sangat kuat yaitu pernikahan. Penikahan dalam undang-undang perkawinan bertujuan untuk membentuk keluarga yang bahagia dan kekal berdasarkan ketuhanan yang Maha Esa. Dalam Kompilasi Hukum Islam (KHI), tujuan pernikahan untuk mewujudkan kehidupan rumah tangga yang sakinah, mawaddah, warahmah.

Setelah pernikahan keharmonisan di dalam rumah tangga adalah idaman setiap pasangan yang telah menikah. Keharmonisan di dalam keluarga adalah suatu hal tang penting dan untuk menciptakannya harus dapat diperhatikan dengan adanya perhatian, pengetahuan, pengenalan terhadap semua anggota keluarga, sikap untuk menerima, peningkatan usaha yang gunanya untuk terciptanya perubahan dan menghilangkan rasa kebosanan. ${ }^{1}$ Dengan adanya keharmonisan tersebut rumah tangga akan menjadi tentram dan damai. Masing masing pasangan harus saling peduli satu sama lain, karena rumah tangga akan menjadi goyah apabila suami dan istri sudah tidak saling mengerti satu sama lain atau hilangnya kepedulian dari pasangan tersebut. Jika hanya salah satu saja yang peduli seperti suami yang peduli terhadap istrinya atau sebaliknya, hal ini menunjukkan komitmen dalam pernikahan mereka sedang goyah. Adapun komitmen yang

1 Noffi Yanti, "Mewujudkan Keharmonisan Rumah Tangga Dengan Menggunakan Konseling Keluarga," Al-Ittizaan: Jurnal Bimbingan Konseling Islam 3, no. 1 (2020): 8, https://doi.org/10.24014/0.8710152. goyah itu merupakan untuk saling setia dan saling membahagiakan. ${ }^{2}$

Pasangan suami istri yang sudah matang adalah pasangan yang telah menemukan prinsip atau komitmen yang kuat didalam hidupnya. ${ }^{3}$ Karena hal tersebut akan mengontrol prilaku-prilaku yang akan merusak hubungan rumah tangga. Hilangnya komitmen di dalam keluarga banyak menimbulkan permasalahan yang tidak diinginkan di dalam keluarga seperti terjadinya kekerasan, percekcokan, hilangnya rasa menghargai sehingga akhirnya menyebabkan perceraian. perceraian merupakan melepaskan ikatan pernikahan dan mengakhirinya. ${ }^{4}$

Pada saat ini banyak sekali kita lihat kasus-kasus perceraian yang semakin meningkat yang disebabkan oleh alasan-alasan tertentu. Meskipun alasan-alasan perceraian tersebut jelas terdapat dalam Undang-Undang Nomor 1 tahun 1974 tentang perkawinan (UU Perkawinan) Pasal 19, bukan berarti perceraian itu dipermudahkan oleh undang undang. Dengan adanya kasus-kasus tersebut, tulisan ini akan memberikan kajian penting di dalam keluarga mengenai perkawinan beserta tujuan dari perkawinan. Disini juga penulis akan menjelaskan hal yang paling penting yang datang setelah perkawinan yaitu hak dan kewajiban yang harus dijalankan oleh suami istri. Karena pemenuhan hak bagi suami istri

2 Ukasyah Habibu Ahmad, Rumah Tangga Seindah Surga (Kisah Islami Keluarga Paling Romantis Sepanjang Masa), ed. Yudi (Yogyakarta: Laksana, 2017), 13.

3 Mohamat Hadroi dan Minhaji, "Makna Kebahagiaan Dan Keharmonisan Rumah Tangga Dalam Perspektif Psikologi," Jurnal Lisan Al-Hal 12, no. 1 (2018): 9.

4 Sayyid Sabiq, Fikih Sunnah, Jilid 4 (Jakarta: Cakrawala Publishing, 2014), 2. 
setara dan sebanding dengan beban kewajiban yang harus dipenuhi. ${ }^{5}$

Dari pemaparan tersebut penulis ingin membuat tulisan tentang membangun keluarga yang samawa menurut Undang-undang No.1 tahun 1974 dan KHI. Yang mana penulisan ini akan menjawab permasalahhan-permasalahan di dalam rumah tangga seperti bagaimana membangun keluarga yang samawa berdasarkan Undang-undang No.1 tahun 1974 dan KHI. Kemudian, apa solusi yang dapat membangun keluarga yang samawa. Dengan tujuan tulisan ini dapat bermanfaat untuk pasangan suami istri dalam membangun rumah tangga dan juga untuk menghadapi gejala- gejala perceraian pada saat ini.

\section{METODE PENELITIAN}

Penelitian merupakan bagian yang penting dalam penanan ilmiah dan berfungsi sebagai alat untuk menyelesaikan persoalan. ${ }^{6}$ Jenis penelitian ini menggunakan studi literatur yang merupakan penelitian yang dilakukan dengan mengumpulkan sejumlah buku-buku, jurnal dan lainnya atau cara untuk menyelesaikan permasalahan dengan menyelusuri sumber tulisan yang pernah dibuat sebelumnya. ${ }^{7}$ Sumber data yang akan digunakan merupakan sumber tertulis dari Undang-Undang Nomor 1 tahun 1974 dan Kompilasi Hukum Islam, buku, jurnal artikel dan lainnya. Dalam penelitian ini, menggunakan analisis deskriftif untuk menemukan kesimpulan dari data-data yang di

5 Bastiar, "Pemenuhan Hak Dan Kewajiban Suami Istri Mewujudkan Rumah Tangga Sakinah: Analisis Disharmonisasi Pasangan Suami Istri Di Kota Lhokseumawe." Jurnal Ilmu Syariah, Perundang-Undangan dan Hukum Ekonomi Syariah (2018): 78.

6 Faisar Ananda dan Arfa and Watni Marpaung, Metodelogi Penelitian Hukum Islam (Jakarta: Prenadamedia Group, 2016), 11.

7"Http://Seputarpengertian.Blogspot.Com/20 17/09/Pengertian-Studi-Literatur.Html.,” n.d. dapatkan. Penelitian ini juga menggunakan pendekatan Yuridis Normatif yang mana bahan dasar utamanya berasal dari UndangUndang Nomor 1 tahun 1974 dan Kompilasi Hukum Islam.

\section{KONSEP PERKAWINAN}

Menurut fiqih perkawinan merupakan akad yang berisi pembolehan laki-laki dan perempuan melakukan hubungan suami istri atau pembolehan bagi laki-laki mengambil manfaat seksual dari alat kelamin perempuan dengan menggunakan lafadz Inkah atau Tazwij atau yang semakna dengan itu. ${ }^{8}$ "Perkawinan ialah ikatan labir batin antara seorang pria dengan seorang wanita sebagai suami istri dengan tujuan membentuk keluarga (rumah tangga) yang bahagia dan kekal berdasarkan ketubanan yang maba esa."(Undang-Undang Nomor 1 Tahun 1974, Pasal 1). Perkawinan menurut hukum Islam adalah "pernikahan, yaitu akad yang sangat kuat atau mïtsaaqon gholiidhan untuk menaati perintah Allah dan melaksanakannya merupakan ibadah." (Pasal 2 KHI).

Pada dasarnya, hukum perkawinan telah dianjurkan dan disarankan kepada setiap manusia, sebagaimana yang tertera di dalam Q.S An-Nur ayat 32, sebagai berikut:

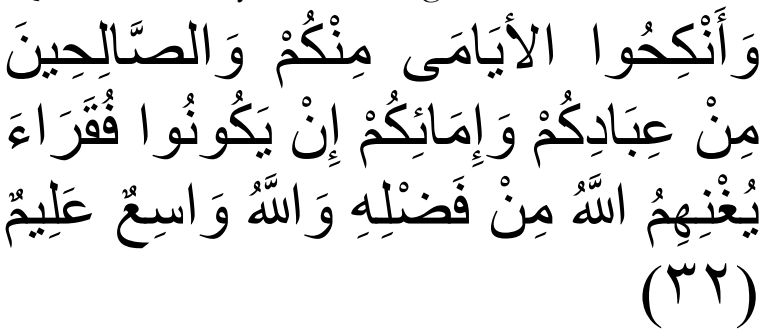

Artinya: "Dan kawinkanlah orang-orang sendirian diantara kamu dan orang-orang yang layak (menikah) dari hamba-hamba sahaya laki-laki dan hamba sahaya yang perempuan. Jika mereka miskin Allab akan memampukan mereka dengan

8 Pangeran Harahap, Hukum Islam Di Indonesia (Bandung: Citapustaka Media, 2014), 47. 
karunianya. Dan Allah maha luas (pemberiannya) lagi maha mengetahui".

Dan dalam hadis Nabi SAW diriwayatkan : "Hai pemuda-pemuda barang siapa yang diantara kamu serta berkeinginan bendak menikah, bendaklah dia menikah. Karena sesunggubnya pernikahan itu dapat merundukan pandangan mata terhadap orang yang tidak halal dilihatnya, dan akan memeliharanya dari godaan syabwat. Dan barang siapa yang tidak mampu menikah, hendaklah dia berpuasa, karena dengan puasa hawa nafsunya terbadap perempuan akan berkurang."

Dengan adanya ayat dan hadis tersebut melaksanakan pernikahan dan membina rumah tangga adalah salah satu anjuran yang harus dilaksanakan. Karena penikahan merupakan jalan yang sangat mulia untuk dilakukan supaya mendapatkan keturunan dengan adanya kehidupan rumah tangga. Dan pernikahan merupakan salah satu asas pokok hidup yang paling utama dalam kehidupan di masyarakat.'

\section{TUJUAN PERKAWINAN}

Tujuan pernikahan juga terdapat dalam undang-undang no.1 tahun 1974 pasal 1 "tujuan membentuk keluarga bahagia dan kekal berdasarkan ketuhanan yang maha esa." Dan juga didalam kompilasi hukum Islam pasal 3 "Perkawinan bertujuan untuk mewujudkan kehidupan rumah tangga yang sakinah mawaddah dan rahmah." Dari sumber tersebut bisa diartikan bahwa pernikahan itu membawa kita kepada kebahagiaan.

Tujuan dilaksanakannya pernikahan ialah untuk mencapai kebahagian, ketenangan di suasana kasih sayang baik lahir maupun batin sesuai dengan surat Ar-Rum ayat (21), sebagai berikut:

9 Sulaiman Rasjid, Fiqib Islam (Bandung: Sinar Baru Algensindo, 2013), 374.

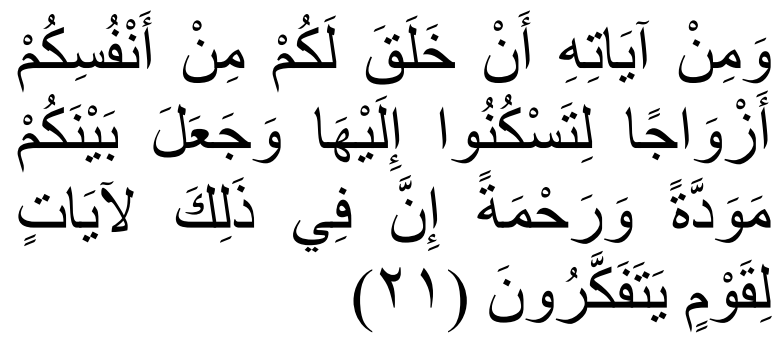

Artinya: "Dan diantara tanda-tanda kekuasaannya ialah Dia menciptakan untukmu istri-istri dari jenis mu sendiri supaya kamu cendrung dan merasa tentram kepadanya dan dijadikannya diantaramu rasa kasib dan sayang. Sesunggungnya pada yang demikian itu benar-benar terdapat tanda-tanda bagi kaum yang berpikir".

Ayat di atas adalah ayat yang seringkali di dengar umat muslim yang ingin melalukan pernikahan dan membangun rumah tangga. Dan ayat tersebut menunjukan bukan hanya tujuan pernikahan melainkan juga apa maksud dari sakinah, mawaddah dan warahmah yang biasa kita sebut (samawa) dan disini akan dijelaskan dari ketiga tersebut:

1. Sakinah

Sebagai mana kita ketahui sakinah berasal dari bahasa arab yang berarti ketentraman, ketenangan dan kedamaian. Maka keluarga sakinah yaitu keluarga yang merasa tentram, tenang dan damai di dalam keluarga. Keluarga yang sakinah ialah keluarga yang terhindar dari kekacauan dan dari keributan. Apabila di dalam keluarga terdapat keributan dan kekacauan maka keluarga tersebut bukanlah keluarga yang sakinah, karena keluarga sakinah adalah keluarga yang aman.

Dengan adanya rasa ketenangan dan ketentraman di dalam keluarga maka keluarga tersebut akan jauh dari adanya pertengkaran, kalau adapun mereka akan mudah menyelesaikannya dikarenakan pikiran yang tenang dan 
jernih akan dapat menghasilkan solusi yang baik bagi keluarga. Kalau tidak adanya sakinah di dalam keluarga maka persoalan yang terjadi di keluarga akan terus terjadi tanpa adanya solusi yang baik dari keduanya, karena tidak adanya ketenangan di dalam berpikir. Dan disinilah pentingnya sakinah di dalam keluarga.

2. Mawaddah

Mawaddah adalah berasal dari bahasa arab yang berarti kasih sayang yang bisa diartikan cinta yang membara atau cinta yang menggebu-gebu. Hal ini memiliki kaitan yang erat dengan sakinah karena rasa aman dan tentram dapat dicapai dengan cara saling mencintai. Perasaan mawaddah ini adalah perasaan yang lumrah bagi semua orang karena dengan adanya rasa sayang yang membara atau menggebu-gebu antara pasangan sangat menjamin kekokohan di dalam keluarga tersebut. Dan perasaan ini mungkin terjadi akibat adanya hal yang indah untuk di pandang baik dari kecantikan ataupun ketampanan, moralitas dan lain sebagainya dari pasangannya.

Dengan adanya mawaddah pasti akan menumbuhkan rumah tangga yang penuh cinta dan kasih sayang. Rasa ingin menjaga diantara pasangan juga semakin kuat karena keduanya sudah merasakan saling melengkapi dengan adanya cinta dan kasih sayang pada keduanya dan hal ini akan menimbulkan sifat yang positif. Apabila tidak adanya mawaddah di dalam keluarga pasti keluarga atau pasangan tersebut merasa sepi dan disinilah akan terjadi sesuatu yang negatif seperti terjadinya perselingkuhan. Hal ini, terjadi akibat sudah hilangnya rasa mawaddah di dalam rumah tangga atau pasangan. Maka dari itu perasaan mawaddah ini harus sangat ditanamkan di dalam keluarga, karena keindahan keluarga yang mawaddah ini adalah salah satu harapan dari rumah tangga yang didambakan oleh setiap orang.

3. Rahmah

Rahmah berasal dari bahasa arab yang artinya rahmat, karunia, rezeki. Maksudnya ialah karunia yang telah diberi tetap terjaga yaitu rasa kasih dan sayang terhadap pasangan dan keluarga. Rahmah disini tidak akan langsung muncul atau timbul begitu saja, tetapi pasti adanya proses yang dilalui antara pasangan atau keluarga, dan rahmah ini pasti tidak akan terwujud apabila antara suami istri tidak menjalankan kewajibannya dengan benar. Maka dari itu pasangan suami istri harus mengetahui kewajiban dan haknya masing-masing supaya keluarga yang rahmah kekal ini akan tetap terus terjaga.

Setelah mengetahui makna yang jelas terkait terbentuknya keluarga yang sakinah mawaddah warahmah setiap pasangan pasti mengetahui bagaimana cara mempertahankan keharmonisan didalam rumah tanggnya sesuai dengan ajaran agama Islam sehingga supaya tidak terjadinya kekacauan didalam keluarga. Sebab, keluarga yang bahagia merupakan sebuah bangunan yang dibuat sepasang suami istri yang menunjukan pengalaman atau 
pengertian satu sama lain dalam sebuah pernikahan dan membentuk rumah tangga. ${ }^{10}$

Dari ketiga sumber diatas dapat diambil bahwa tujuan pernikahan secara jelas ialah:

1. Supaya terwujudnya keluarga yang benar-benar bahagia sejahtera tentram dan sedamai-damainya.

2. Supaya mendapatkan keturunan yang sah dan kedua orang tua bertanggung jawab terhadap anaknya.

3. Supaya terhindar dari maksiat dan dapat menjaga diri dari lainnya. ${ }^{11}$

UPAYA PEMBENTUKAN KELUARGA YANG SAKINAH MAWADDAH WARAHMAH

Sebelum pembentukan rumah tangga atau keluarga yang samawa kita harus mengetahui dulu hak dan kewajibannya masing-masing. Dengan adanya hak dan kewajiban, maka akan menjadi saling memahami keadaan di dalam rumah tangga. Pada dasarnya antara hak dan kewajiban pasangan suami istri merupakan suatu hal yang timbal balik, maksudnya ialah apa yang menjadi kewajiban seorang suami merupakan hak bagi istri, dan apa yang menjadi kewajiban seorang istri merupakan hak bagi suami. ${ }^{12}$

Adapun hak dan kewajibannya sudah tertera di dalam Undang-Undang Nomor 1 Tahun 1974. Pada Pasal 30 yang berbunyi "suami istri memikul kewajiban yang lubur untuk menegakkan rumah tangga yang menjadi sendi dasar dari susunan masyarakat'. Di dalam undang undang ini suami dan istri memiliki hak yang

10 Mohamat Hadroi dan Minhaji, "Makna Kebahagiaan Dan Keharmonisan Rumah Tangga Dalam Perspektif Psikologi, 6.

11 Rafi' Udin, Mendambakan Keluarga Tentram (Keluarga Sakinah), ed. Abdul Rasyid (Semarang: Intermasa, 2001), 4.

12 Mohamad Ikrom, "Hak Dan Kewajiban Suami Isteri Perspektif Al-Quran," Jurnal Qalamuna 1, no. 1 (2015): 23-40. setara dalam arti mempunyai hak dan kewajiban yang sama dalam membangun rumah tangganya. Hal tersebut diatur dalam pasal-pasal berikut :

\section{Pasal 31}

1) Hak dan kedudukan suami istri adalah seimbang dengan hak dan kedudukan suami dalam kehidupan rumah tangga dan pergaulan bidup bersama dengan masyarakat.

2) Masing-masing pibak berhak untuk melakukan perbuatan bukum.

3) Suami adalab kepala keluarga dan istri ibu rumah tangga. ${ }^{13}$

Dalam pasal 31 baik ayat 1 maupun 2 dari undang - undang perkawinan tersebut sudah cukup jelas mensejahterakan antara hak dan kedudukan suami dan istri dalam kehidupan masyarakat cukup sesuai dengan tatanan hidup mayarakat di zaman yang modern saat ini. ${ }^{14}$ Suami memiliki hak menjadi kepala rumah tangga, oleh karena itu ia harus bertanggung jawab terhadap keselamatan keluarga dan rumah tangganya. Dan istri memiliki hak sebagai ibu rumah tangga oleh karena itu tugas utama istri adalah melayani suami dan mengatur kebutuhan keluarga dan rumah tangga.

Pada pasal 32 dan pasal 33 yaitu sama sama mengatur tentang apa yang harus dilakukan oleh sepasang suami istri di dalam kehidupan berkeluarga. ${ }^{15}$ Adapun pasalnya ialah:

\footnotetext{
13 Undang-Undang RI Nomor1 Tabun 1974 Tentang Perkawinan Dan Kompilasi Hukum Islam (Bandung: Citra Umbara, 2012).

${ }^{14}$ Laurensius Mamahit, "Hak Dan Kewajiban Suami Isteri Akibat Perkawinan Campuran Ditinjau Dari Hukum Positif Indonesia," Lex Privatum 1, no. 1 (2013): 19.

15 Wiratni Ahmadi, "Hak Dan Kewajiban Wanita Dalam Keluarga Menurut Undang-Undang No.1 Tahun 1974 Tentang Perkawinan," Jurnal Hukum Pro Justitia (2008): 382.
} 
Pasal 32

1) Suami istri harus mempunyai tempat kediaman yang tetap.

2) Rumah tempat kediaman yang dimaksud dalam ayat 1 pasal ini ditentukan oleh suami istri bersama.

Pasal 33

"Suami istri wajib saling cinta mencintai, hormat menghormati, setia dan memberi bantuan labir bathin yang satu kepada yang lain."

Dalam pasal tersebut, menjelaskan bahwa suami harus memiliki tempat tinggal yang tetap, dan dalam menentukan tempat tinggal tersebut harus di tentukan oleh suami istri secara bersama. Kemudian, kewajiban saling menghormati dan saling membantu antara suami istri secara batin sangat diperlukan seperti suami berkewajiban melindungi dan memberi kebutuhan istri sesuai dengan kemampuannya, sedangkan istri mengurus keluarga dan rumah tangga.

Adapun kewajiban kewajiban suami istri terdapat dalam Pasal 34 undang - undang perkawinan No.1 tahun 1974 yang menyatakan bahwa:

1) Suami wajib melindungi istri dan memberikan segala sesuatu keperluan bidup berumah tangga sesuai dengan kemampuannya.

2) Istri wajib mengatur urusan rumah tangga sebaik-baiknya.

3) Jika suami atau istri melalaikan kewajibannya masing-masing dapat mengajukan gugatan kepada pengadilan.

Dalam ayat (1) tersebut dijelaskan bahwa suamilah yang membiayai kehidupan rumah tangga dan kewajiban memberikan nafkah kepada istri, akan tetapi pemberian keperluan tersebut harus sesuai dengan kemampuan suami, adapun maksud dari kemampuannya ialah sesuai dengan keadaan suami. Dan dalam ayat (2) di jelaskan istri wajib mengatur rumah tangga dengan baik, dan melaksanakan sesuatu yang diperlukan di dalam rumah tangga.

Dengan penjelasan undang-undang tersebut sudah sangat jelas tentang tanggung jawab seorang suami istri. Hanya tinggal menjalankan sesuai posrinya masing masing karena mengenai hak dan kewajiban di dalam Undang-Undang Nomor 1 tahun 1974 cukup jelas. $^{16}$

Adapun Hak dan kewajiban suami istri di dalam KHI terdapat pada pasal berikut:

\section{Pasal 77}

1) Suami istri memikul kewajiban yang lubur untuk menegakekan rumah tangga yang sakinah mawaddah dan rahmah yang menjadi sendi dasar dari susunan masyarakat.

2) Suami istri wajib saling cinta mencintai, hormat menghormati, setia dan memberi bantuan labir batin yang satu kepada yang lain.

3) Suami istri memikul kewajiban untuk mengasub dan memelihara anak-anak. mereka, baik mengenai pertumbuban jasmani, rohani maupun kecerdasannya dan pendidikan agamanya.

4) Suami istri wajib memelihara kehormatannya.

5) Jika suami atau istri melalaikan kewajibannya masing-masing dapat mengajikan gugatankepada pengadilan agama. ${ }^{17}$

Dalam pasal diatas menjelaskan bahwa hak dan kewajiban suami istri adalah suatu hal yang timbal balik dan juga menjelaskan suami istri harus melaksanakan kewajiban masingmasing dengan baik. Saling menghormati dan saling menghargai di dalam rumah tangga juga

16 Pagar, Himpunan Peraturan Perundang Undangan Peradilan Agama Di Indonesia (Medan: Perdana Publishing, 2015), 19.

17 Undang-Undang RI Nomor1 Tabun 1974 Tentang Perkawinan Dan Kompilasi Hukum Islam. 
merupakan suatu yang dibutuhkan didalam keluarga dan juga menjaga kehormatan atau nama baik dari pasangannya. Karena itu akan menjadi contoh yang baik buat keturunannya karena suami istri juga diberi kewajiban untuk mengasuh dan memelihara anak-anak mereka dan disini dapat terlihat kewajiban dan hak antara suami istri tersebut memiliki kesetaraan.

\section{Pasal 78}

1) Suami istri harus mempunyai tempat kediaman yang tetap.

2) Rumah kediaman yang dimaksud dalam ayat (1) ditentukan oleh suami istri bersama.

Dalam pasal ini jelaskan bahwa suami harus memiliki tempat tinggal atau kediaman yang tetap dan layak buat keluarganya dan penentuan tempat tinggal yang dimaksud harus adanya diskusi atau musyawarah antara pasangan suami istri. Apabila hak dan kewajiban telah terjalankan oleh suami dan istri maka dapatlah mereka hikmah pernikahan. Hikmahnya ialah suami istri dapat saling membina kehidupan keluarga dan memupuk rasa kasih sayang serta mendorong tumbuhnya jiwa keibuan dan kebapak-an. ${ }^{18}$

\section{SOLUSI MEMBENTUK KELUARGA YANG SAKINAH MAWADDAH WARAHMAH}

Upaya pembentukan keluarga sakinah, mawaddah dan warahmah dapat kita liat dari berbagai macam sisi atau berbagai macam keadaan yang tengah dijalankan oleh seseorang dalam mewujudkan kehidupan yang bahagia didalam keluarga dan disini penulis memiliki beberapa upaya yang bisa dilakukan didalam pembentukan keluarga yang sakinah mawaddah warahmah.

1. Menjaga hubungan komunikasi
Dalam keluarga komunikasi satu sama lain sangat penting dilakukan karena dengan adanya komunikasi yang baik dan benar dan saling tidak menyinggung satu sama lain dan saling menghargai pendapat itu adalah salah satu sifat yang bisa mempererat hubungan satu sama lain. Konikasi disini bisa kita gambarkan dengan adanya kata- yang membuat hati bahagia baik dari istri kesuami dan dari suami keistri dan juga dari orang tua kepada anaknya kelak. Disini juga senantiasa melakukan musyawarah untuk kepentingan bersama dan juga saling memelihara kepercayaan dan menyembunyikan rahasia kedua belah pihak.

2. Kebutuhan biologis

Kebutuhan biologis antara suami istri semakin mempererat kebahagiaan apabila keduanya saling memahami dan mengerti akan maunya. Sebagaimana di dalam alquran juga disebutkan bahwa perempuan yang sudah dinikahi oleh laiki-laki maka ia adalah selimut bagi laki-laki dan disini juga dapat kita lihat bahwa dengan adanya biologis yang baik maka baik pula hubungan tersebut. Dan banyak juga kita lihat diluar sana banyak terjadinya perceraian akibat biologis yang tidak baik dan membuat sepasang kekasih tidak nyaman dan menginginkan perpisahan. Dan biologis disini bukan hanya diartikan berhubungan suami istri. Biologis tersebut banyak macamnya seperni memenuhi nafkah istri karena laki-laki adalah pemimpin bagi wanita dan dari situ dapat kita lihat bahwa kebutuhan kehidupan juga termasuk

18 Armia, Fikih Munakahat (Medan: CV. Manhaji, 2015), 57. 
ALHURRIYAH :

Jurnal Hukum Islam
eISSN: 2549-4198

pISSN: 2549-3809 kebutuhan biologis yang bersifat jasmani.

3. Menjaga penampilan

Penampilan bisa juga menjadi dampak kuatnya suatu keluarga. Dengan menjaga penampilan masing-masing bisa membuat hilangnya rasa bosan satu sama lain. Penampilan sangan sensitif sekali di dalam keluarga dikarenakan kebiasaan orang yang sudah berkeluarga penampilannya sudah tidak terjaga lagi dan sudah tidak ada lagi hal yang menarik dan hal ini membuat perselingkuhan terjadi karena melihat yang lain berpenampilan menarik. Bagi suami istri walaupun sudah menikah harus tetap menjaga penampilan dikarenakan dengan adanya penampilan yang menarik pandangan pun tidak akan teralihkan kepada yang lain.

4. Mengatur ekonomi keluarga

Mengenai ekonomi keluarga sangat penting dilakukan karena ini adalah salah satu hal yang sensitif alangkah baiknya mengenai perekonomian keluarga harus dibahas sebelum pernikahan. ${ }^{19}$ Karena di dalam fungsi perekonomian keluarga meliputi manejemen keuangan, penjarian nafkah dan penggunaan dana berguna untuk memenuhi segala kebutuhan di dalam rumah tangga. Di dalam keluarga keuangan pasti tidak akan pernah stabil. Oleh sebab itu, pasangan suami istri harus bisa mengambil tindakan. Hal yang bisa dilakukan ialah mengontrol perencanaan keuangan, hindari hutang

19 Yasin Yusuf Abdillah, "Perjanjian Perkawinan Sebagai Upaya Membentuk Keluarga Bahagia (Tinjauan Maqāșid Asy-Syarī'Ah)," Al-Abwal: Jurnal Hukum Keluarga Islam 10, no. 2 (2018): 174. https://doi.org/10.14421/ahwal.2017.10205. piutang kalau pun mengambil hutang harus adanya kesepakatan berdua dan yang terakhir mulailah menabung buat kedepannya baik buat keturunan dan keperluan yang akan datang.

\section{KESIMPULAN}

Perkawinan merupakan merupakan salah satu asas pokok di dalam kehidupan bermasyarakat dan dengan adanya pernikahan dapat membuat orang terhindar dari adanya fitnah. Adanya pernikahan atau perkawinan akan mendapatkan hikmah yang sangat banyak baik dari segi psikologi, kesehatan dan sosial. Dan tujuan dilaksanakan pernikahan tersebut ialah untuk mencari kesenangan dunia dan akhirat bukan hanya melepaskan nafsu akan tetapi menimbulkan kasih sayang yang menciptakan keluarga sakinah mawaddah warahmah sesuai dengan tujuan nikah itu sendiri.

Hak dan kewajiban pernikahan merupakan tombak suatu ikatan pernikahan. Karenan dengan mengetahui tugas dan kerjaan masing-masing jadinya tidak ada simpang siur di dalam rumah tangga. Dengan itu komitmen dan tanggung jawablah yang akan dipegang didalam bahtera rumah tangga. Hal ini sangat jelas diterakan di dalam Undang-Undang Nomor 1 tahun 1974 dan KHI.

Upaya pembentukan rumah tangga yang baik ialah sesuai dengan yang penulis sampaikan menjaga hubungan komunikasi, kebutuhn biologis, dan menjaga penampilan, mengatur ekonomi keluarga dengan melakukan hal tersebut rumah tangga akan selalu akur dan bahagia dengan adanya perhatian dan tampilan yang menarik maka hubungan di dalam rumah tangga akan terhindar dari perselingkuhan. 
ALHURRIYAH :

Jurnal Hukum Islam
eISSN: 2549-4198

pISSN: 2549-3809

\section{DAFTAR KEPUSTAKAAN}

Abdillah, Yasin Yusuf. Perjanjian Perkawinan Sebagai Upaya Membentuk Keluarga Bahagia (Tinjauan Maqāṣid Asy-Syarī'Ah). Al-Ahwal: Jurnal Hukum Keluarga Islam 10, no. 2 (2018): 16577. https://doi.org/10.14421/ahwal.2017.10205.

Ahmad, Ukasyah Habibu. Rumah Tangga Seindah Surga (Kisah Islami Keluarga Paling Romantis Sepanjang Masa). Edited by Yudi. Cet-1. Yogyakarta: Laksana, 2017.

Ahmadi, Wiratni. "Hak Dan Kewajiban Wanita Dalam Keluarga Menurut Undang-Undang No.1 Tahun 1974 Tentang Perkawinan.” Jurnal Hukum Pro Justitia, 2008.

Arfa, Faisar Ananda \&, and Watni Marpaung. Metodelogi Penelitian Hukum Islam. Cet-1. Jakarta: Prenadamedia Group, 2016.

Armia. Fikih Munakahat. Medan: CV. Manhaji, 2015.

Bastiar. "Pemenuhan Hak Dan Kewajiban Suami Istri Mewujudkan Rumah Tangga Sakinah: Analisis Disharmonisasi Pasangan Suami Istri Di Kota Lhokseumawe.” Jurnal Ilmu Syariah, Perundang-Undangan dan Hukum Ekonomi Syariah (2018).

Harahap, Pangeran. No TitleHukum Islam Di Indonesia. Cet-1. Medan: Citapustaka Media, 2014.

“Http://Seputarpengertian.Blogspot.Com/2017/09/Pengertian-Studi-Literatur.Html.," n.d.

Ikrom, Mohamad. "Hak Dan Kewajiban Suami Isteri Perspektif Al-Quran.” Jurnal Qalamuna 1, no. 1 (2015): 23-40.

Mamahit, Laurensius. "Hak Dan Kewajiban Suami Isteri Akibat Perkawinan Campuran Ditinjau Dari Hukum Positif Indonesia." Lex Privatum 1, no. 1 (2013).

Minhaji, Mohamat Hadroi \&. "Makna Kebahagiaan Dan Keharmonisan Rumah Tangga Dalam Perspektif Psikologi." Jurnal Lisan Al-Hal 12, no. 1 (2018): 5-36.

Pagar. Himpunan Peraturan Perundang Undangan Peradilan Agama Di Indonesia. Medan: Perdana Publishing, 2015.

Rasjid, Sulaiman. Fiqib Islam. Cet-63. Bandung: Sinar Baru Algensindo, 2013.

Sayyid Sabiq. Fikih Sunnah. Jilid 4. Jakarta: Cakrawala Publishing, 2014.

Udin, Rafi'. Mendambakan Keluarga Tentram (Keluarga Sakinab). Edited by Abdul Rasyid. Cet-1. Semarang: Intermasa, 2001.

Undang-Undang RI Nomor1Tabun 1974 Tentang Perkawinan Dan Kompilasi Hukum Islam. Cet-10. Bandung: Citra Umbara, 2012.

Yanti, Noffi. "Mewujudkan Keharmonisan Rumah Tangga Dengan Menggunakan Konseling Keluarga." Al-Ittizaan: Jurnal Bimbingan Konseling Islam 3, no. 1 (2020): 8. https://doi.org/10.24014/0.8710152. 